\title{
GSO and John Knauss
}

\author{
Robert A. Duce \\ Texas A\&M University - College Station, Texas USA
}

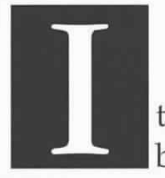

t has been almost 40 years since John Knauss

brought an old ship and a new science to the University of Rhode Island (URI). In 1962 URI decided to upgrade its Narragansett Marine Laboratory, which had focused primarily on biological studies in the coastal regions around Rhode Island, to an open ocean comprehensive graduate oceanography program. URI turned to John Knauss to lead the development of what quickly became known as GSO (Graduate School of Oceanography), not only because he was recognized as an outstanding young physical oceanographer from the Scripps Institution of Oceanography, but also because he said he could bring a ship to URI if he came! With the help of the Office

\section{URI turned to John Knauss}

to lead the development

of what quickly became

known as GSO

(Graduate School of Oceanography), not only because he was recognized

\section{as an outstanding}

young physical oceanographer

from the Scripps Institution

of Oceanography,

but also because he said

he could bring a ship to URI

if he came! of Naval Research and Scripps, John did indeed obtain ar II floating machine shop, converted it for use as a research vessel, renamed it $\mathrm{R} / \mathrm{V}$ Trident and in early 1962 sailed it through the Panama Canal and up to Narragansett. John brought with him from Scripps two new faculty members for GSO - Dale Krause and David Schink, to join the biologists already at the Narragansett Marine Laboratory, who included Charles and Marie Fish, Saul Saila, Ted Smayda, and John Sieburth, among others. To transport the household belongings, cars, etc. of the Californians to Rhode Island they loaded everything on Trident for the trip through the canal and up the east coast. If you look closely at Figure 1, you can see Dale

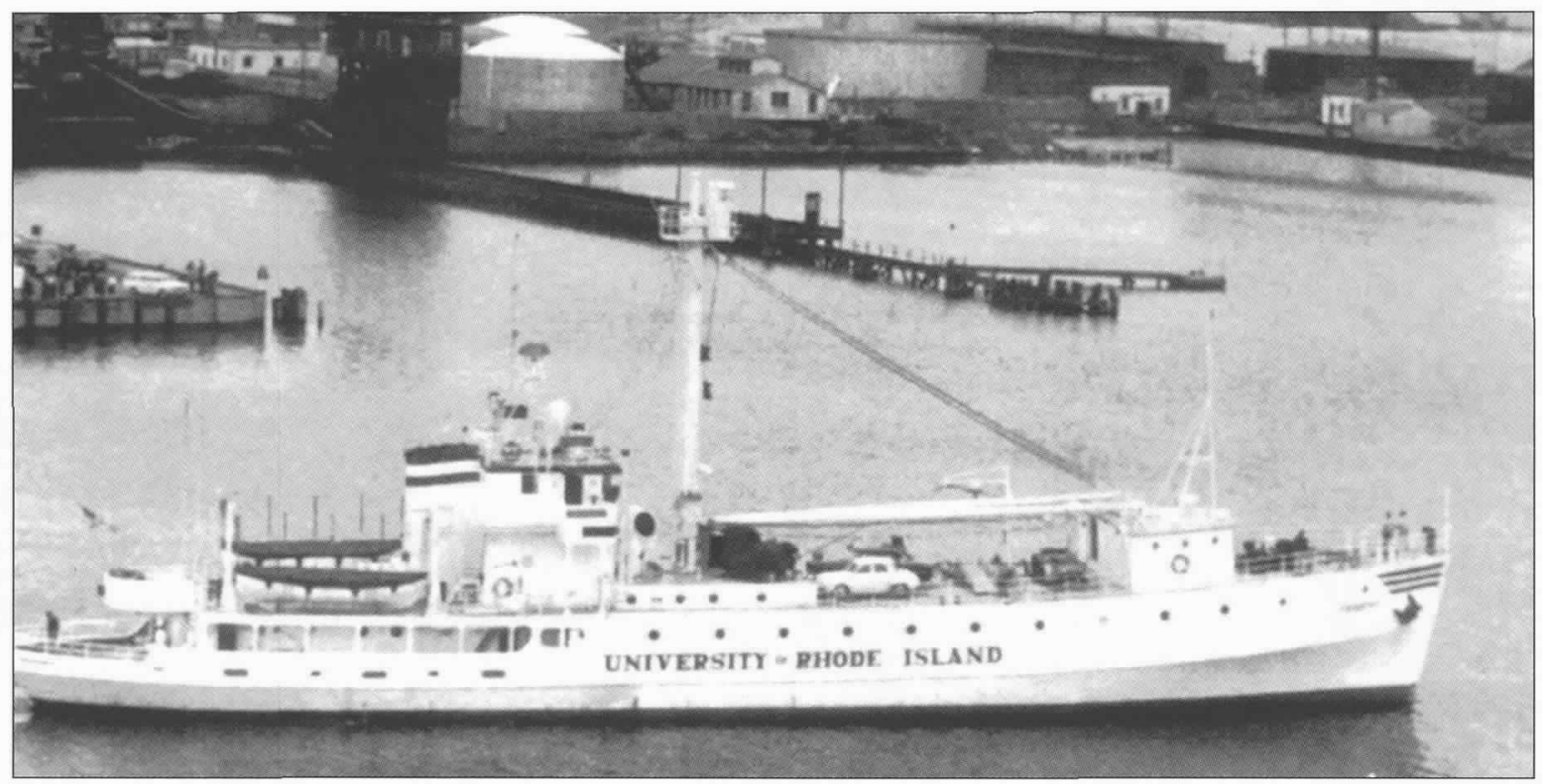

Figure 1. Trident sailing past Providence in the early 1960s enroute to GSO from San Diego with a load of Californians' cargo. 


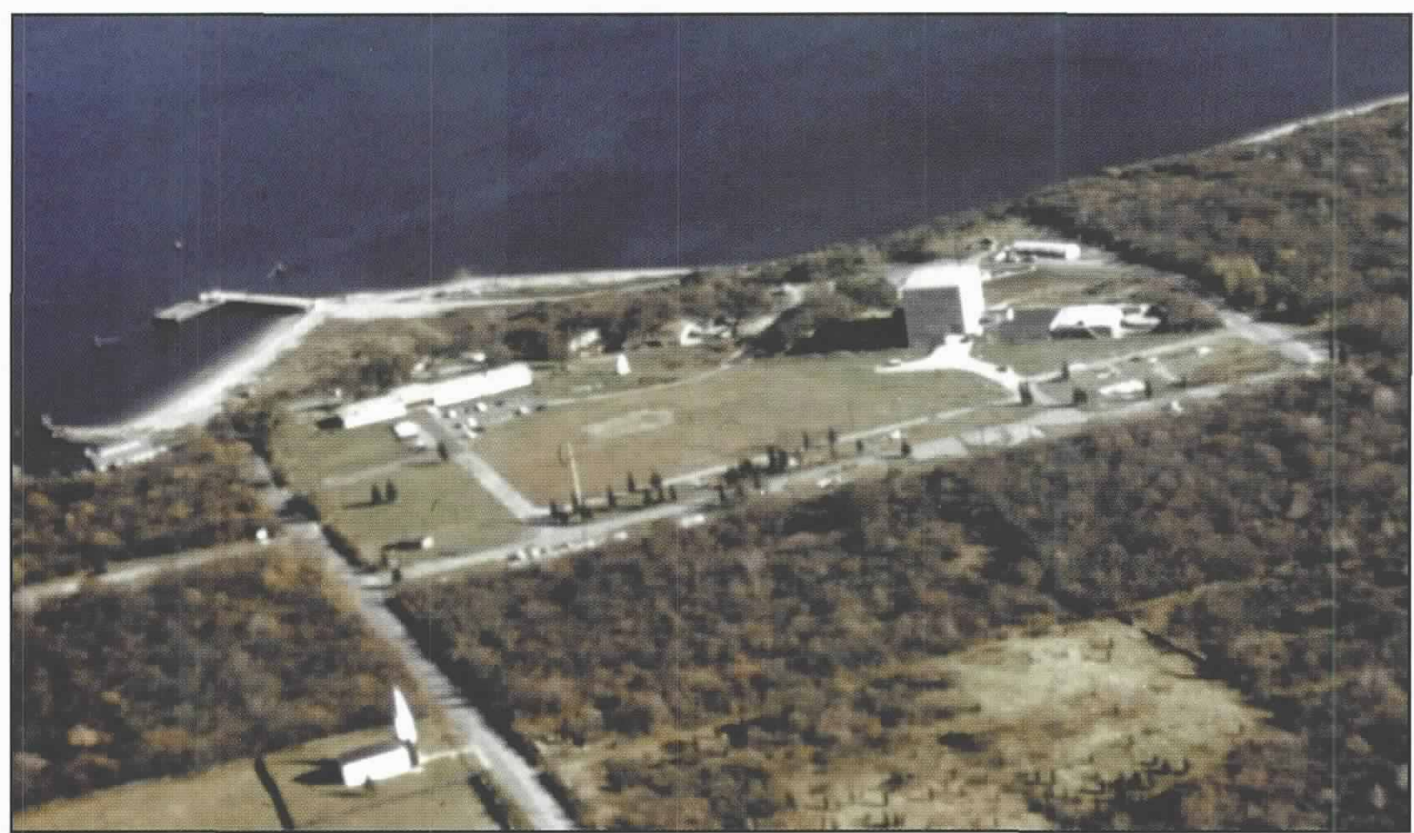

The GSO Bay Campus in 1965, just a few years after John Knauss' arrival.
Krause's Renault Dauphine resting comfortably on the deck as the Trident moved toward Narragansett. Both John and R/V Trident served the faculty, students, and staff well at GSO for many decades. At its retirement Trident had completed cruises equivalent to 8.5 times around the world. At his retirement from the deanship of GSO (but not active life and service) 26 years later, John had developed one of the finest graduate education and research institutions in oceanography in the world. URI had made good investments indeed!

Early on John recognized that while oceanography might be the cornerstone of marine programs at URI, it was certainly not the only important marine-related area that could grow and develop. Through the help of John's leadership and vision, URI developed programs and departments in many marine-related fields in the 1960s and 1970s, including the Departments of Ocean Engineering, Marine Resource Economics, and Marine Affairs, as well as a program to train commercial fishermen. In addition to these marine-related academic programs, a number of marine service related groups were also formed, some just before John arrived, but most after. These included such groups as the Division of Marine Resources, the Law of the Sea Institute, the Rhode Island Sea Grant Program (one of the first four Sea Grant Programs in the nation), the International Center for Marine Resource Development, and the Coastal Resources Center. John believed that many of these other programs fitted effectively within other components of the University, outside of GSO, and his goal was to make URI a truly marine-oriented university. To do this in a sensible fashion some overall guidance was needed for all of these marine efforts, so URI also gave John the title of Vice Provost for Marine Programs and eventually Vice President for Marine Affairs, with direct line responsibility for many of these organizations, but coordinating responsibility for them all.

How was John Knauss able to develop such a high quality and internationally recognized oceanography and marine-based program at the state university of the smallest state in the nation? John himself has said it was due to three factors - geography, a young university, and very strong university leadership. Clearly those three factors were extremely important.

- Rhode Island, after all, is the "Ocean State," and even in the early 1960s essentially everyone in Rhode Island knew about, worked on, or were concerned about the ocean in general and Narragansett Bay in particular. It is important to note that while Rhode Island may be the smallest state, it probably has the largest ratio of coastline to land area of any of the contiguous United States. In addition, the Bay Campus, where GSO is located, is only 6 miles from the main campus of the University - making strong interactions among faculty, students and staff much easier than at many institutions with graduate marine programs located at shoreside campuses.

- URI had really just become a new university at the time John went there, having offered its first Ph.D. in 1960. It was looking for exciting new areas in which to expand and to make significant contributions. And the people of Rhode Island really valued and supported GSO and were proud of it.

- URI did have a strong leader during those years in the early 1960s in President Francis Horn, who was committed and devoted to the development of the Graduate School of Oceanography. Fran Horn, 
among other things, was a strong supporter of the Sea Grant Program and strongly encouraged John, who organized the first national planning conference for Sea Grant universities in Newport, Rhode Island in 1965, as described by Margaret Leinen in this issue.
Right from the beginning John banned departments within the Graduate School of Oceanography. As all of us in academia know, such artificial boundaries can be among the greatest barriers to collegiality, to collaboration, to cooperation, and to true interdisciplinary efforts that we can erect. And John let his faculty do what they

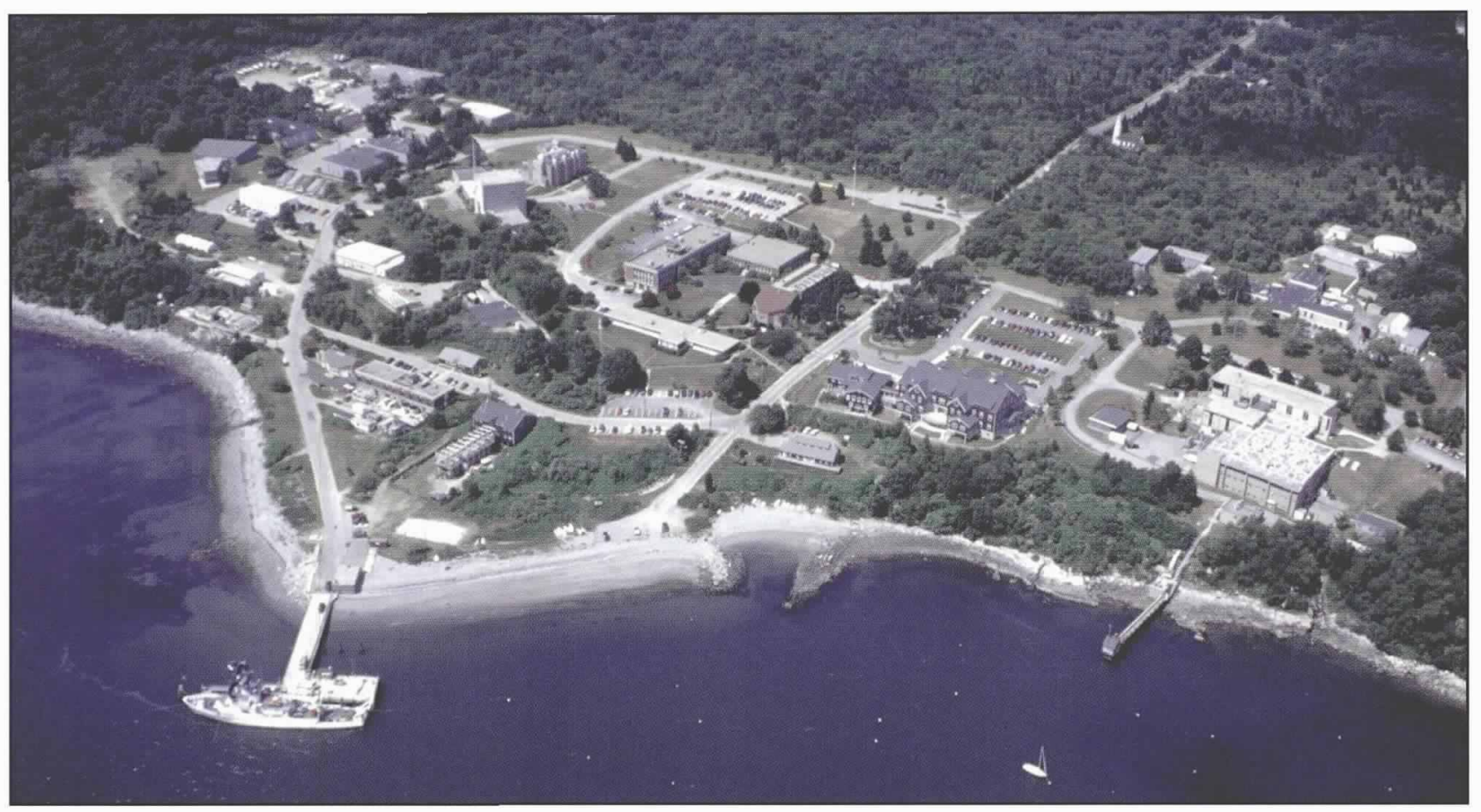

The GSO Bay Campus in 1999.

An important part of the success of that conference and the Sea Grant College Program that developed from it was the strong and close personal relationship that developed between John and the new senator from Rhode Island, Claiborne Pell. Not too long after that meeting legislation introduced by Senator Pell, the Sea Grant Act, was passed and the Sea Grant Program was off and running. Senator Pell continued to be a strong supporter of GSO and URI for many years, and the Pell Marine Science Library on the Bay Campus is named in his honor. As an aside, I recall that among the most enjoyable aspects of my tenure as dean at GSO were the times Senator Pell would come by the office, never letting me know he was coming, walk in, shut the door, sit down and just talk about the ocean and his many interests in it. He was clearly one of GSO's and John Knauss' strongest supporters.

But while the three factors above clearly were important for the development of URI's marine programs, I believe the most central and critical factor was John Knauss himself. For one thing, John seemed to know just what to do and when to do it. He made very few, if any, strategic errors during the formative years of GSO. did best. Throughout his career as Dean, John tried never to bother those of us on the faculty with administrative trivia. He wanted us to be successful as teachers and researchers, and he did everything he could to make that as easy for us as possible. As Dale Krause points out, "His approach was to provide opportunity and resources, which then became our responsibility to take advantage of. His approach was low-key, noncontroversial, yet decisive. He solicited input on major decisions. On occasion he was willing to be outvoted - although this was not common. Once a decision was made, that decision tended to hold - not because of rigidity but because careful consideration has gone into that decision. Nonetheless, John was always ready to hear appeals. John is a kind and decent man."

John always had good contacts at the state and federal level, and this gave him a sense of the possible that the rest of us did not have at that time. He could thus gauge the realistic things to do, and guided GSO in those directions. His connections and affiliations and impacts on the field of oceanography were numerous, ranging from being a member of the Stratton Commission and Chair of National Advisory 
Committee on Oceans and Atmosphere (NACOA), to Chair of the National Academy of Sciences (NAS)/National Research Council (NRC) Ocean Sciences Committee and member of the NAS/NRC Ocean Policy Committee, the latter two being forerunners of the current Ocean Studies Board. (And of course his involvement in those types of activities continued and even accelerated after he retired from the Deanship, becoming Administrator of the National Oceanographic and Atmospheric Administration [NOAA] and President of the American Geophysical Union, among many other responsibilities.)

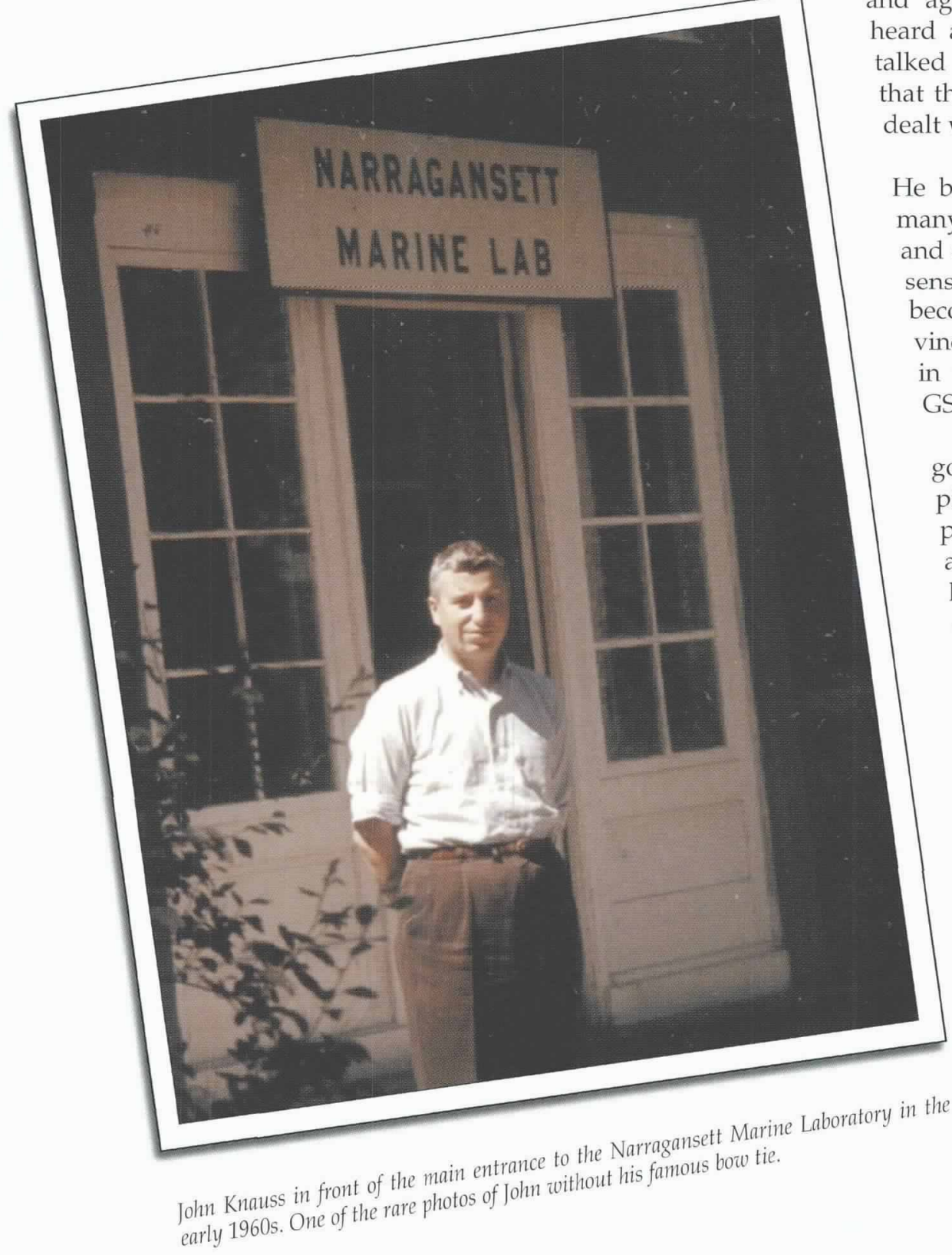

John always protected his faculty, not only against administrative trivia, but from the daily trials and tribulations of maintaining a largely independent campus and in dealing with the upper university administration. But in addition, as Michael Pilson points out, "John always protected the upper administration. He never complained about them to the faculty!" Pilson also accurately states "John was remarkably loyal to his faculty. He is a unique individual with a remarkable strength of mind and character, and he was able to deal very effectively with difficult persons." John had his battles with strong-minded people on campus, as would any administrator with a young, active, and aggressive faculty. But one rarely ever heard about these, and John certainly never alked about them or showed any indication that they had happened. The problems were dealt with and one moved on.

John made excellent hiring decisions. He brought in some outstanding faculty many of them still at GSO, a few moved on, and some have passed away now. He could sense when a new Ph.D. was going to become a star, and he had a knack for convincing the more senior scientists that it was in their very best interests to relocate to GSO. They were rarely sorry they did so.

John was willing to take risks. Just going to URI in those early days and picking up an old World War II ship proves that. But he did it often, and usually with great success. I recall one risk he tried to take, but which did not pan out. Some time in the 1970s the atmospheric sciences program at New York University (NYU) was being closed down. John tried very hard to move that program lock, stock and barrel to GSO. The NYU Meteorology Department was quite good at that time, and I have always wondered how the future course of GSO might have changed if he had been able to pull that one off. Certainly looking at it from today's perspective, a strong graduate research program in both the ocean and atmospheric sciences within the same administrative structure would be ideally positioned to address many of the most critical issues we are facing today in our global environment. In this case John was 


\section{The Dog Memos}

January 27, 1972: Although I am not prepared to ask you to keep your dogs off campus, I feel I must insist that you keep the dogs out of the buildings. This decision is based on a small, but hopefully random, survey in which those who want the dogs removed from buildings far outnumber those who don't care, or prefer to have the dogs in the building. In this one case, at least, the minority rights of dogs and dog lovers are going to be ignored. Please, henceforth, keep your dog outside.
Among the more delightful communications from John Knauss to the Bay Campus community were the famous series of "dog memos," which John issued periodically from the early 1970s through the mid 1980s. Shown here are two of them. perhaps just too far ahead of his time and was unable to convince the upper administration of the value of such a merger.

John took another risk relative to the atmospheric sciences in the late 1970s which I believe was very successful, and of which I certainly heartily approved. He recognized the growing importance of atmospheric chemistry, both to society and in its relation to the ocean, and he recognized that this was going to be a major source of research funding in the future. Under his leadership a strong program in atmospheric chemistry with a number of faculty developed, one of the very best such programs in the nation at the time. His support enabled GSO and URI to build the first building at any university in the United States devoted solely to the study of the chemistry of the atmosphere.

Relative to risks, I always like to tell my own story in this regard. It turns out that both Dana Kester and I had applied for the same single faculty position in chemical oceanography at GSO in 1969. John decided to offer the job to both of us, sure that one of us would turn it down. However, both of us accepted, and John took a risk and somehow managed to hire both of us. I don't know how he did it, and we never even heard about it until many years later.

John also always rem a in ed, and remains to this day, an oceanographer at heart. For most of his tenure as Dean he insisted on continuing to teach the core course in physical oceanography, which all students had to take. He would rarely miss a student seminar on Monday afternoons, and his insightful and penetrating questions from the front row kept many a graduate student from sleeping the night before his or her seminar. His ability to get to the nub of a problem ranged well beyond the graduate seminars. One might often think John was dozing or thinking about something else while you were explaining an issue to him or telling him about your problems, when all of a sudden out would come a question or a comment so relevant and insightful that you were almost embarrassed to have been bothering him!

John Knauss' many leadership qualities were a major factor in one of the most important characteristics of GSO during his tenure as dean - a tremendous sense of community on the Bay Campus. Yes, there was an excellent teaching and research program there, and federal funding grew by leaps and bounds in the many and diverse marine programs on campus. New buildings seemed to sprout everywhere, and a new ship was found to replace Trident. But above all this was the fact that everyone enjoyed being there and working together there and being part of a self-contained and successful organization in a beautiful place. The environment was right in so many ways! And we all appreciated John's leadership abilities and style that made it all happen and work. As Dale Krause put it, "John and Lynne Knauss became de facto heads of a large extended family encompassing GSO, neighbors, 


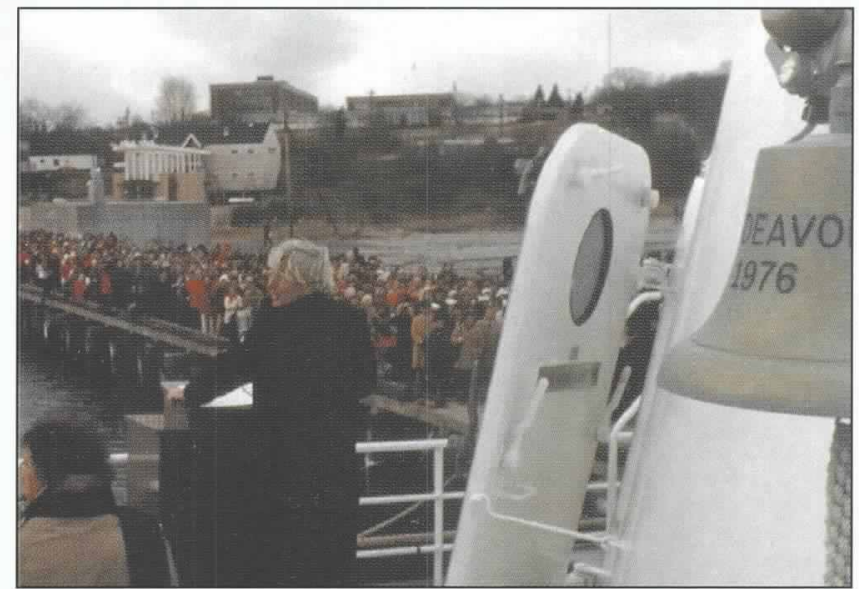

John Knauss during the christening ceremonies for R/V Endeavor in 1977.

and a host of other people, including University colleagues and visitors."

I believe that sums it up very well - an outstanding leader with great vision who cared very much about the people who worked for and with him. URI and GSO are very fortunate indeed that John Knauss left California for Rhode Island almost 40 years ago. All of us who were or are at GSO say simply "Thank you, John."

\section{Acknowledgements}

I would first like to acknowledge John Knauss himself for being a shining example for me of both an excellent leader and a truly fine person. When I had the unenviable task, but great honor, of following John as dean of GSO he told me he would never second guess any decision that I made. And he never did! For that I am eternally grateful, as I know there were many times when he could have done so very easily. I also want to thank all my former colleagues at GSO for many discussions about GSO over the years. Special thanks go to Dale Krause, Michael Pilson, and David Schink for their insights and discussions during the writing of this paper, and to Ken Hinga for finding the illustrations that have been used.

Jo ohn is a member of a rare breed: academic administrators who are natural leaders. Today, as higher education enters a period of change and more intense competition, there is an argument swirling around the higher education associations as to whether we need leaders rather than managers. The answer, of course, is that we need people with both skills.

John is a great manager. During my years at the University of Rhode Island, we were beset by a range of problems that tested our managerial skills to the utmost - from our emergence as a research university to surviving a recession. Whether mastering his budget, building a new building, contracting for a ship, or making the Graduate School of Oceanography (GSO) run smoothly everyday, John was a master.

But, to me, his role as a leader was even more impressive. From a small, almost primitive laboratory, he build a world renowned academic enterprise. His clear and articulate vision was the rallying point. His persistence and determination was the engine. His integrity was the moral compass. His natural openness was the bedrock of his warm relationship with all those GSO touched.

John's enjoyment of life and work swept along those around. I was always not only impressed with how hard everyone worked, but also with how much fun they had in the process.

John was, simply, the best academic administrator that I worked with in the course of a long career.

Frank Newman former President of University of Rhode Island Narragansett, Rhode Island USA 